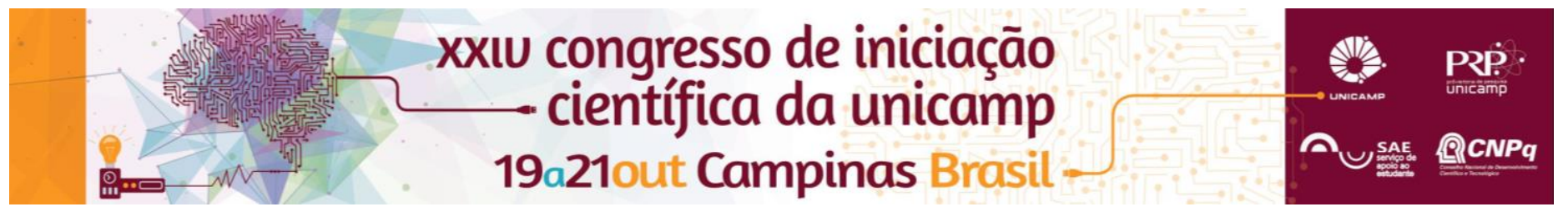

\title{
O Processo Criativo em Dança: sensações, sentidos e imaginário.
}

\author{
Lívia M. T. Sene*, Marisa M. Lambert.
}

\begin{abstract}
Resumo
A presente pesquisa aprofundou-se no estudo dos conceitos de sensação e percepção como caminho para a criação em dança, dando continuidade à investigação das obras "As Contribuições das Abordagens Somáticas na Construção dos Saberes Sensíveis em Dança: um estudo sobre o projeto Por Que Lygia Clark?” (COSTAS, 2010), e do livro eletrônico "Sensorimemórias: um processo de criação da Companhia Perdida" (MORAES, 2012). Desenvolveu-se primordialmente por meio de laboratórios de criação pautados em exercícios de sensibilização envolvendo a percepção do espaço e a exploração de materiais com texturas diversas. Auxiliaram a intersecção prática-teoria a leitura de textos de Fayga Ostrower sobre os percausos do processo criativo, outros artigos sobre percepção, sinestesia e criatividade, além de bibliografias do educador somático e bailarino Hubert Godard, abordando o espaço de ação criativa. A dramaturgia corporal e cênica do trabalho se desdobrou de aproximações com a performance, enquanto modo de atuação, e se constituiu a partir do contato com o filme A Espuma dos Dias (Michel Gondry) e de visitas de observação e experimentação corporal ao Parque Vicentina Aranha. A análise de todo o percurso apoiou-se em apontamentos arquivados em um caderno de registros. Como resultado, chegou-se a produção de um vídeodança que procura apresentar a interrelação entre os elementos investigados.
\end{abstract}

\section{Palavras-chave: \\ Criação em Dança, Sensação, Poética do Imaginário.}

\section{Introdução}

Esta pesquisa teve como foco investigações centralizadas na criação de uma obra cênica cujo processo fosse embasado na sensibilização corporal a partir da percepção de materiais de texturas diversas. Ao longo desse percurso, foram aprofundados os estudos acerca dos conceitos de percepção, sinestesia e criatividade por meio das obras "Acasos e Criação Artística" (OSTROWER, 1990), "Espaço Fenomenológico" (GODARD, 2005), "Fenomenologia da Percepção" (MERLEAU-PONTY, 1999), entre outros. Foram realizados laboratórios de experimentação em sala com base nos estudos sobre sensibilização corporal realizados na etapa anterior desta pesquisa, no período de janeiro a julho de 2015. Tais estudos foram enriquecidos pelo contato com o filme "A Espuma dos Dias" (Michel Gondry, 2013), pelo livro "A Água e os Sonhos" (BACHELARD, 1989) e pela aproximação com a Performane Art por meio da oficina "Encantoamento: preparação para quinas e cantos" e pela disciplina "Performance", ministradas pelas artistas e pesquisadoras Ana Behatriz e Elisa Belém, respectivamente. A oficina "Encantoamento" inspirou-me a buscar espaços ao ar livre para investigações, o que levoume ao Parque Vicentina Aranha, onde realizei observações, experimentações corporais e a gravação de um videodança. As visitas foram registradas por meio de fotos, vídeos e anotações, desenhos ou colagens em um caderno.

\section{Resultados e Discussão}

A percepção é o lugar de conexão entre o indivíduo e seu meio. Constantemente recebemos incontáveis estímulos sensoriais e nossos mecanismos de percepção exercem a função de filtrá-las, fazendo com que alguns deles sejam mais notados que outros. Esse fenômeno, segundo Fayga Ostrower, pode também ser chamado de "acasos significativos" (OSTROWER,1990), um acontecimento de aparente irrelevância que se traduz de maneira extremamente significativa em relação à nossa existência individual. Isso ocorre porque estamos receptivos a partir de algo que já existe em nós ou que buscamos e encontra-se no acaso uma oportunidade de se manifestar (idem ibidem). O resultado dessa pesquisa foi permeado por diversos "acasos significativos", aflorados do percurso de um ano de estudos e investigações, que contribuíram de forma relevante para a construção da obra cênica. O contato com o filme "A Espuma dos Dias" se interconectou com minha pesquisa de elementos sensoriais, trazendo uma espacialidade para os materiais explorados em laboratório, devido a sua atmosfera surrealista e sinestésica. As visitas e experimentações no Parque Vicentina Aranha, inspirada pela oficina "Encantoamento", trouxeram novas temáticas e poéticas para o processo, levando a reflexões acerca da relação do corpo e do ser com os diversos estímulos presentes no espaço, pois segundo Godard, "[...] eu estou no espaço e o espaço está em mim." (GODARD, 2005)
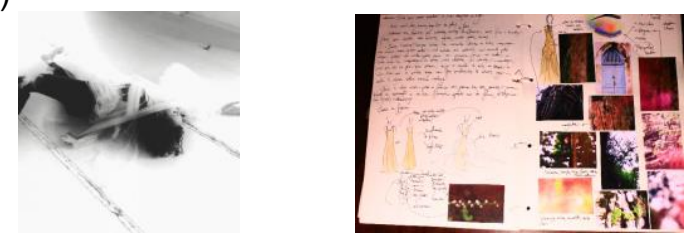

Figura 1. Experimentação com o tule realizada em sala.

Figura 2. Caderno de Registro.

\section{Conclusões}

A experiência desta pesquisa enriqueceu grandemente a minha vivência artística, pois uniu o imaginário poético de diversas vias de expressão à prática da dança. Permitiume concluir a importância da relação prática-teórica, sendo ambas fundamentais para o amadurecimento do artista da cena.

PIBIC SAE.

\section{Agradecimentos}

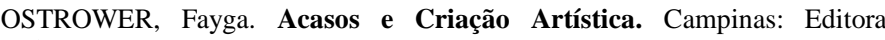
Unicamp, 1990.

GODARD, Hubert. Espaço Fenomenológico. Columbia, 2005. 